\title{
Os Malês nas margens do Atlântico Negro: desafios da interiorização e da internacionalização da Unilab no Recôncavo Baiano
}

Malês on the shores of the Black Atlantic: challenges of internalization and internationalization of Unilab in Recôncavo Baiano

\section{Daniel De Lucca e Rafael Palermo Buti}

\section{(2) OpenEdition Journals}

\section{Edição electrónica}

URL: http://journals.openedition.org/aa/7676

DOI: $10.4000 /$ aa. 7676

ISSN: 2357-738X

\section{Editora}

Programa de Pós-Graduação em Antropologia Social (UnB)

\section{Edição impressa}

Paginação: 119-144

ISSN: 0102-4302

\section{Refêrencia eletrónica}

Daniel De Lucca e Rafael Palermo Buti, «Os Malês nas margens do Atlântico Negro: desafios da interiorização e da internacionalização da Unilab no Recôncavo Baiano», Anuário Antropológico [Online], v.46 n.1 | 2021, posto online no dia 03 janeiro 2021, consultado o 27 abril 2021. URL: http:// journals.openedition.org/aa/7676 ; DOI: https://doi.org/10.4000/aa.7676

\section{(c) $(1) \odot$}

Anuário Antropológico is licensed under a Creative Commons Atribuição-Uso Não-Comercial-Proibição de realização de Obras Derivadas 4.0 International. 


\title{
Os Malês nas margens do Atlântico Negro: desafios da interiorização e da internacionalização da Unilab no Recôncavo Baiano
}

\author{
Malês on the shores of the Black Atlantic: challenges of internalization and \\ internationalization of Unilab in Recôncavo Baiano \\ DOI: https://doi.org/10.4000/aa.7676
}

\begin{abstract}
Daniel De Lucca • Universidade da Integração Internacional da Lusofonia Afro-Brasileira - Brasil

Doutor em Ciências Sociais pela Universidade Estadual de Campinas (Unicamp), professor e vice-coordenador do curso de Relações Internacionais da Universidade da Integração Internacional da Lusofonia Afro-Brasileira (UNILAB), em São Francisco do Conde-BA.
\end{abstract}

Rafael Palermo Buti • Universidade da Integração Internacional da Lusofonia Afro-Brasileira - Brasil

Doutor em Antropologia Social pela Universidade Federal de Santa Catarina (UFSC), professor e coordenador do curso de Ciências Sociais da Universidade da Integração Internacional da Lusofonia Afro-Brasileira (UNILAB), em São Francisco do Conde-BA.

O artigo situa o campus dos Malês no "Atlântico negro", problematizando dimensões do processo de interiorização e internacionalização da Unilab no Recôncavo Baiano por meio de fragmentos da experiência quilombola e africana no território, e considerando a presença do petróleo nas práticas universitárias. A proposta é discutir como as ideias de alteridade e racismo podem intersectar questões econômicas, políticas e ambientais atreladas à cadeia de exploração do "ouro negro". Após definir problemas e contextualizar o campus dos Malês no Recôncavo, o artigo examina conexões quilombolas com a universidade para então discutir as conflitualidades vividas pelos estudantes africanos na cidade de São Francisco do Conde. Metodologicamente, o trabalho está amparado na análise e descrição de experiências educativas e nas pesquisas desenvolvidas pelos próprios estudantes. O texto levanta processos que confluem e se cruzam no campus dos Malês, ele mesmo um microcosmo no qual se entrelaçam diversos fios e pontos da diáspora afro-atlântica, projetada a partir de diferentes lugares e histórias de engajamento, luta e encontro.

Unilab. Recôncavo Baiano. Quilombolas. Estudantes africanos. Petróleo.
The article places the Malês campus in the "Black Atlantic", problematizing dimensions of the process of Unilab's interiorization and internationalization in Recôncavo Baiano through fragments of the quilombola and African experience in the territory, and considering the presence of oil in university practices. The proposal is to discuss how the ideas of otherness and racism can intersect economic, political, and environmental issues linked to the "black gold" exploitation chain. After defining problems and contextualizing the Malês campus in Recôncavo, the article examines quilombola connections with the university to then discuss the conflicts experienced by African students in the city of São Francisco do Conde. Methodologically, the work is supported by literature, educational experiences and research developed by the students themselves. The text raises processes that converge and cross on the Malês campus, itself a microcosm in which several threads and points of the Afro-Atlantic diaspora intertwine, projected from different places and stories of engagement, struggle, and encounter.

Unilab. Recôncavo Baiano. Quilombolas. African students. Oil. 


\section{No enclave petrolífero'}

No dia 5 de fevereiro de 2019, um grupo de estudantes e professores do curso de Relações Internacionais da Universidade da Integração Internacional da Lusofonia Afro-Brasileira (Unilab) foi visitar a Refinaria Landulpho Alves-Mataripe (RLAM). O grupo era composto por estudantes provenientes de Angola, Brasil, Cabo Verde, Guiné-Bissau, Moçambique e São Tomé e Príncipe. Planejada meses antes, a "visita técnica" demandou alguns condicionantes: todos deveriam estar utilizando calças e calçados fechados; portar documentos de identificação, RG para os nacionais e RNE para os estrangeiros; e não seria possível fotografar, filmar ou gravar áudio em seu interior ${ }^{2}$. O controle na entrada era rígido, o espaço comportava mais de 2 mil funcionários uniformizados, estava apinhado de substâncias combustíveis e encontrava-se isolado por um inflexível aparato de segurança.

O percurso foi pré-definido pelos anfitriões e teve início no memorial da refinaria, onde a história do petróleo no Brasil era relembrada e celebrada. Painéis e cartazes contavam da descoberta do "ouro negro" na Bahia e explicavam que aquela refinaria era a primeira do país, construída na costa da Baía de Todos os Santos e inaugurada em 1950. Dois anos depois, o complexo receberia a visita do então presidente Getúlio Vargas e, em 1953, a Petrobrás incorporaria a refinaria como parte de seu patrimônio. O memorial da companhia exaltava o "pioneirismo" de seus empreendedores e a "importância estratégica dos combustíveis fósseis" como condição para o "desenvolvimento e independência econômica do país". Esta narrativa, acompanhada de outras ideias-força, como a "transparência" e a "responsabilidade social e ambiental da Petrobrás", permaneceu como pedra de toque durante toda a visita.

O lugar era uma gigante estrutura metálica, com uma intrincada trama de tubulações escuras e avermelhadas pela ferrugem, apoiada numa enorme e árida plataforma de concreto horizontal, construída sobre o mangue, e que projetava ininterruptamente gases na atmosfera por alongados canos verticais. $O$ cheiro da química era forte, e a parafernália industrial contrastava com a verdejante paisagem costeira do Recôncavo Baiano ao fundo. Um engenheiro da Petrobrás, nosso guia na visita, se esforçou por explicar os procedimentos técnicos com os hidrocarbonetos: extração, refino, compartimentação e distribuição. Contudo, os estudantes tinham suas próprias questões. Queriam saber como funcionava a variação do preço do petróleo nacional e internacionalmente; qual era a atuação da Petrobrás na África; se havia investimento em outras fontes alternativas de energia; porque tinha parado de produzir biodiesel; como a refinaria se relacionava com as populações do Recôncavo; e como a economia do petróleo impactava o ecossistema, a produção agrícola e a segurança alimentar regional.

Funcionários contornaram as perguntas justificando não saber ou não poder responder, e que deveríamos remeter as questões à matriz da empresa no Rio de Janeiro. Argumentaram que era a primeira vez que recebiam uma turma das ciências humanas e estavam mais acostumados com estudantes de ciências
1 Agradecemos, de antemão, às leituras atentas e contribuições importantes das/os pareceristas do Anuário Antropológico (UnB) e dos membros do ÓRBITA - Observatório das Relações Internacionais da Unilab.

2 Visita organizada pelas professoras Tatiana Carrascal, Cínthia Campos e Daniel De Lucca, como atividade das disciplinas "Economia Política Internacional", "Segurança Alimentar Global" e "Geografia Política e Geopolíticas do Sul Global”. 
(que poderíamos chamar de) "menos humanas": engenharia, química e geologia. Nós, visitantes, sabíamos do poder exercido pela Petrobrás em São Francisco do Conde, dos frequentes vazamentos de petróleo na região e dos conflitos com as comunidades que vivem do mangue, temas que foram completamente negados e silenciados por nossos interlocutores.

Além disso, alguns estudantes africanos possuíam uma memória viva e um saber próprio a respeito das consequências danosas associadas à exploração mineral em seus países - degradação ambiental, dependência econômica, concentração de renda e corrupção da classe política -, conceitualizada pela literatura especializada como "maldição dos recursos naturais" (Sachs; Werner, 2001). As questões dos estudantes ficaram sem respostas, mas em sala de aula discutimos sobre o controle de informações e a dimensão do segredo que permeou toda a visita. Também refletimos sobre como, tanto no Recôncavo Baiano quanto nos contextos africanos, a riqueza prometida pelos grandes empreendimentos extrativistas não era partilhada com os grupos subalternos locais, justamente aqueles que mais sofrem com a hostil vizinhança dos gases, fluidos e dispositivos petrolíferos.

\section{A Unilab, o Atlântico negro e o ouro negro}

A visita ao enclave petrolífero suscita reflexões sobre as conexões locais e globais e constitui um bom exemplo das possibilidades de fusão das práticas de ensino e de pesquisa, mobilizando temas de investigação e a curiosidade dos estudantes no contato direto com os problemas do mundo. Com estas questões em vista é que, neste artigo, situamos a Unilab nas duas margens do "Atlântico negro”. Com este conceito, Paul Gilroy (2001) buscou destacar o oceano como uma "zona de contato" entre experiências apartadas, geográfica e historicamente, de memória e luta, em torno da raça e da identidade negra. Trata-se, portanto, de uma noção que enfatiza a dupla consciência e as formas culturais polifônicas, originadas por corpos negros dispersos numa estrutura diaspórica e internacional, policêntrica e interligada ${ }^{3}$.

Ao conectar a Unilab ao Atlântico negro, inserimos também outra "problemática de cor", considerando a presença do "ouro negro" nas práticas universitárias. A reflexão levantada por um pescador quilombola de São Francisco do Conde aponta desde já para a importância do tema. Segundo ele: "os três pretos que tem valor na cidade são Pelé, petróleo e café, e não o povo”. Assim, nosso objetivo é discutir como, a partir das experiências de internacionalização e interiorização da Unilab no Recôncavo, as ideias de alteridade e racismo podem intersectar e friccionar questões econômicas, políticas e ambientais atreladas à cadeia de exploração do petróleo - em sua forma bruta, uma matéria morta, grudenta e tóxica, que há anos mancha e perturba as águas, as terras e os seres do mundo Atlântico. A imagem das águas oceânicas e do óleo em movimento é útil, pois sugere também uma linguagem mais fluida e aberta para lidar com situações, problemas e conhecimentos que transbordam as fronteiras nacionais, identitárias e disciplinares.
3 O livro de Gilroy focaliza a experiência anglófona e secundariamente a francófona, mas no prefácio à edição brasileira sugere uma "correção pela ideia de um Atlântico Sul negro" (Gilroy, 2001, p. 12) acenando para os inúmeros estudos sobre a diáspora afro-atlântica no "mundo lusófono". Sobre este último, Miguel Vale de Almeida (2007) forjou a noção de "Atlântico pardo", uma expressão irônica e provocativa, utilizada de modo crítico para caracterizar a narrativa apologética do projeto de miscigenação que foi hegemônico, em parte do século XX, no Brasil e em Portugal colonial. 
Anunciada como um projeto inovador, a Unilab foi criada em 2010, mas sua gestação se deu em período anterior, a partir de um comitê formado por componentes do governo presidencial de Luiz Inácio Lula da Silva (2003-2010), da sociedade civil brasileira, representada pelo movimento negro, e atores internacionais ligados às instituições dos Estados membros da Comunidade dos Países de Língua Portuguesa (CPLP) (Malomalo, 2018). Seu projeto é resultado da convergência de pelo menos três diferentes eixos das políticas públicas: 1) o Programa de Apoio a Planos de Expansão e Reestruturação de Universidades Federais (REUNI, 20072012); 2) as políticas afirmativas de promoção da igualdade racial e combate ao racismo; 3) e a política externa brasileira, "ativa e altiva", voltada para o estabelecimento de novas aproximações diplomáticas, econômicas e de cooperação com os países do Sul Global ${ }^{4}$.

Ainda que o primeiro destes eixos de atuação, vinculado à interiorização do ensino superior, seja uma dimensão fundamental das atividades desenvolvidas pela Unilab, são os dois últimos, conectados às dinâmicas afro-brasileiras, que marcam sua diferença no conjunto das outras Instituições Federais do Ensino Superior (IFES). Ao acolher estudantes do Brasil e dos Países Africanos de Língua Oficial Portuguesa (PALOP), além de Timor-Leste, e formar profissionais para ensinar, pesquisar e atuar com as temáticas e os contextos africanos e afro-brasileiros (Unilab, 2013), a universidade pode ser interpretada como corolário tanto da "política afirmativa no Brasil" quanto da "política africana do Brasil". De um lado, ela é resultado da histórica luta dos movimentos negros e da construção de políticas de combate à desigualdade racial que, entre outras coisas, estabeleceu a regulamentação da lei de cotas para populações afrodescendentes e a obrigatoriedade do ensino de história e cultura africana e afro-brasileira; de outro lado, ela é um instrumento de cooperação internacional com o continente africano, região transformada pelos governos petistas num espaço estratégico para projeção geopolítica brasileira no Atlântico Sul ${ }^{5}$.

A sede da Unilab situa-se no Ceará, na região do Maciço do Baturité, onde há três campi: Palmares, Liberdade e Aurora. Os Malês foi o último a ser criado. Localizado na Bahia, ele é um campus fora de sede com cerca de 95\% do seu corpo discente negro, e cujas atividades curriculares estão voltadas prioritariamente para questões étnico-raciais, africanas e diaspóricas. O presente texto parte, no entanto, das preocupações e dos aprendizados de dois antropólogos brancos, formados nos centros universitários do Sul e Sudeste do Brasil, que passaram a integrar o corpo docente deste campus. Ao enfatizarmos nossa posição, queremos apontar não só para os possíveis limites e impasses, por vezes implícitos, da análise aqui proposta, mas também destacar a importância da solidariedade e do aprendizado na luta e na educação antirracista, cujas preocupações têm sido crescentes em nossas atividades de ensino, pesquisa e extensão.

Nas próximas seções contextualizamos o campus dos Malês no Recôncavo, o conectamos à vida quilombola da região, para então discutir estranhamentos e conflitualidades vividas pelos estudantes internacionais em São Francisco do Conde. O percurso do texto levanta fragmentos da experiência quilombola e afri-
4 As instituições educacionais são entidades privilegiadas para inculcação de certos valores culturais, habilidades linguísticas, tradições intelectuais e, até mesmo, visões políticas (BOURDIEU, 199). Neste sentido os programas de cooperação internacional no campo da educação também podem ser entendidos como tecnologias de construção de hegemonia (Gramsci, 1991). Os Estados cooperantes que oferecem formação de recursos humanos por meio de acordos internacionais (como o Brasil) buscam potencializar sua influência no exterior, na expectativa de que tais quadros, após formarem-se, mantenham e valorizem as relações com o país no qual receberam sua educação, promovendo-o.

5 Neste último aspecto, o projeto da UNILAB assemelha-se ao da UNILA (Universidade Internacional Latino-Americana), ambos voltados para a internacionalização do ensino superior (o primeiro gestado no âmbito da CPLP, o segundo do Mercosul) e convergentes com os objetivos da política externa dos governos Lula (2003-2010) e, com menor intensidade, Dilma Rousseff (2011-2016): a afirmação do Brasil no entorno estratégico africano e sul-americano, buscando consolidar-se como liderança regional no hemisfério Sul (Saraiva, 2012; Nasser; Moraes, 2014). 
cana no território, como dimensões inerentes aos processos de interiorização e internacionalização da universidade e também do petróleo. Metodologicamente o trabalho está amparado na análise e descrição de experiências educativas e nas pesquisas desenvolvidas pelos próprios estudantes.

\section{Malês ontem e hoje}

O campus dos Malês está sediado em São Francisco do Conde, município do Recôncavo Baiano localizado na porção norte da Baía de Todos os Santos e distante $77 \mathrm{~km}$ de Salvador. A cidade, cuja formação urbana remonta aos primórdios da colonização portuguesa no continente americano, sempre teve uma relação muito intensa com a capital, com as cidades vizinhas e os núcleos agrícolas do meio rural. Historicamente marcada pela exploração da mão de obra escravizada, pelo latifúndio e pela monocultura da cana de açúcar, a região foi um importante palco de lutas por liberdade e emancipação na primeira metade do século XIX, tendo protagonismo nas guerras de independência do Brasil contra Portugal, e posteriormente transformando-se no epicentro das rebeliões escravas contra o cativeiro imposto pelos senhores de engenho.

Ao analisar estas revoltas, João Reis (1986) caracterizou a vida social da época, cuja elite estava aterrorizada pelo risco de "haitianização do Brasil" e encontrava-se dependente do tráfico de gente escravizada no golfo de Benin, "egressos de sociedades guerreiras e muitos deles adeptos do islã, uma religião militante e em expansão na África” (Reis, 1992, p. 101). Foram inúmeras as sublevações escravas, e a mais célebre aconteceu em 1835. Conhecida como a Revolta dos Malês, iniciou na capital e pretendia se espalhar pelo Recôncavo. O termo derivado da palavra imalê, que significa "muçulmano” em língua iorubá, referia-se aos negros de origem islâmica que organizaram o levante. Os negros nascidos no Brasil, chamados de "crioulos", ficaram fora da Revolta dos Malês. Por trás da divisão entre africanos e crioulos havia outras distinções não superadas pela linha de cor. Diferente dos africanos trazidos ao Brasil mediante o tráfico transatlântico, a maioria dos crioulos nascera na condição de escravizados: o que implicava relações diferentes com o cativeiro e, por sua vez, formas distintas de resistência à escravidão (Reis, 1986). De todo modo, ao assumir a designação Malês para um dos seus campi, a Unilab afirma-se como um "lugar da memória" (Nora, 1993), no esforço de trazer ao tempo presente a história da resistência africana na Bahia ${ }^{6}$.

Como resultado dos seus processos históricos, o Recôncavo possui enorme influência africana, sendo objeto de importantes pesquisas sobre a diáspora e as relações raciais ${ }^{7}$. A região é considerada berço da capoeira e lugar onde teriam surgido as primeiras manifestações do "samba de roda”, expressão musical, coreográfica e poética, proclamada patrimônio oral e imaterial pela UNESCO em 2005. Segundo o IBGE, São Francisco do Conde possui cerca de 40 mil habitantes e é um dentre os municípios brasileiros com o maior percentual de negros declarados,
6 A memória da Revolta dos Malês ganhou maior destaque nas obras do início do século $X X I$, representada em palcos de teatro, minissérie televisiva e no importante romance literário Um defeito de cor, de Ana Maria Gonçalves (2006), também no documentário Allah, Oxalá - na trilha Malê, dirigido por Francirosy Campos Barbosa, e na produção de um filme de ficção histórica ainda em curso, sob a direção de Antonio Pitanga. 
cerca de $90 \%$ da população. Ali, a grande presença de terreiros de candomblé, bem como os grupos culturais, as festas, os reisados, maculelês e carurus, são anunciados pelos locais como expressões de uma tradição popular "negra” ou "afro-baiana”.

Presente na cerimônia de inauguração do campus dos Malês, em maio de 2014, o ex-presidente Luiz Inácio Lula da Silva falou de "dívida do Brasil com a África" e da necessidade de "solidariedade" e "reconhecimento" . Já em 2017, quando retornou ao campus como patrono da primeira turma de formandos, num contexto político distinto e em que seu partido não estava mais no governo federal, o ex-presidente foi mais enfático em seu discurso: "Vocês, negros e negras, africanos que estudam aqui não devem nenhum favor a esse país e nem o Brasil está fazendo nenhum favor a vocês" (...) "vocês têm de resistir, porque a integração do Brasil com a África é uma necessidade geopolítica do século XXI" . A criação do campus dos Malês foi também resultado das articulações dos poderes locais. Rilza Valentin, a primeira prefeita negra da cidade, teve papel importante na negociação com o Ministério da Educação para estabelecer um campus da Unilab em São Francisco do Conde. Ela possuía um plano de desenvolvimento urbano integrado à Universidade. Mas seu falecimento, em 2016, impediu a continuidade daquele projeto.

Como o campus dos Malês ainda não dispunha de lugar próprio, um edifício escolar municipal foi cedido temporariamente enquanto a construção de dois novos prédios da universidade estava em andamento. As obras nunca foram concluídas e o campus permaneceu circunscrito àquele pequeno edifício localizado ao lado da carcaça das construções abandonadas ${ }^{10}$. Na medida em que novas turmas foram se matriculando, as instalações cedidas pela prefeitura foram ficando pequenas e insuficientes, superlotadas e precarizadas. Para contornar este problema, aulas começaram a ocorrer em salas cedidas por outras escolas públicas, mais distantes, no período noturno. Esta solução colocou novos obstáculos, não só devido à necessidade de transporte para estudantes e professores, mas porque uma das escolas foi alvo de dois assaltos organizados. Pessoas se machucaram e perderam seus bens, e a violência fez com que estudantes, professores e funcionários se recusassem a retornar àquele espaço sem a segurança adequada.

No primeiro semestre de 2020, o campus dos Malês contava com 45 servidores técnico-administrativos, além de 10 profissionais terceirizados, estes, em boa medida, oriundos do próprio município. Para os munícipes, trabalhar na Unilab significa um importante marcador de status social e inserção no universo acadêmico, determinando, em algumas ocasiões, no próprio ingresso, pessoal ou de algum membro familiar, nos cursos oferecidos pela instituição. Até setembro daquele ano havia também funcionários cedidos pela prefeitura, órgão responsável pela manutenção predial.

No mesmo período, o campus acolhia 1.087 estudantes e 90 professores (sendo 89 servidores efetivos e 1 substituto), oferecendo, por meio do Instituto de Humanidades e Letras (IHL), 6 cursos presenciais: o Bacharelado Interdisciplinar em Humanidades (BHU) e o de Relações Internacionais, além das licenciaturas de Ciências Sociais, História, Pedagogia e Letras. Os estudantes destes cursos pro-
7 Destacamos o clássico de Pierre Verger (2002), Fluxo e refluxo do tráfico de escravos entre o Golfo do Benin e a Bahia de Todos os Santos dos séculos XVII a XIX, e o estudo de comunidade de Harry Hutchinson (1957), inspirado no grande projeto Columbia/UNESCO, que conduziu trabalho de campo em São Francisco do Conde na época em que os primeiros poços de petróleo estavam sendo perfurados.

8 Disponível em: http://Unilab.edu.br/noticias/2014/05/13/ campus-dos-males-e-inaugurado-em-sao-francisco -do-conde-na-bahia/. Acesso em: 04 jul. 2020.

9 Disponível em: http:// www.Unilab.edu.br/ noticias/2017/08/21/cerimonia-confere-grau-a-formandos-do-bacharelado-em-humanidades-do-campus-dos-males/. Acesso em: 04 jul. 2020.

10 A empresa responsável, $\mathrm{RCl}$ Construções e Meio Ambiente Ltda, abandonou a obra faltando aproximadamente 30\% para sua conclusão. $\mathrm{O}$ caso tramita na justiça. Em função do abandono do contrato pela empresa, a UNILAB devolveu aproximadamente 4 milhões de reais ao Tesouro Nacional. 
vêm principalmente do Recôncavo e dos PALOP, mas também de outras regiões da Bahia e do Brasil. O projeto da Unilab inicialmente preconizava a presença de $50 \%$ de discentes internacionais, o que nunca ocorreu. Mesmo assim, o campus apresenta uma significativa presença de internacionais, com 282 estudantes africanos. Além de 14 professores estrangeiros, não só dos PALOP, mas também de outros países, como República Democrática do Congo, Cuba, Colômbia, Portugal, Espanha e Itália. A desigualdade racial, no entanto, permanece como clivagem fundamental entre docentes e discentes no campus, os primeiros são de maioria branca e os segundos quase todos negros, o que provoca, por vezes, algumas tensões. Mesmo afirmando o protagonismo "afro-brasileiro", a Unilab nunca lançou editais com cotas étnico-raciais nos concursos para professores.

Se por um lado a maioria dos docentes dos Malês não é negra, por outro, os currículos dos cursos não são muito brancos ${ }^{11}$. Os projetos pedagógicos curriculares (PPCs) dialogam com os paradigmas pós e decoloniais, valorizando abordagens críticas, interdisciplinares e interseccionais, em conexão com as teorias antirracistas e as chamadas epistemologias do Sul. Logo nos primeiros semestres, estudantes do Bacharelado em Humanidades têm contato com a história da África, da Revolução Haitiana e da Revolta dos Malês, e aproximam-se de autores como Frantz Fanon e Amílcar Cabral, Lélia Gonzalez e Abdias Nascimento. Por vezes, esses currículos colocam desafios concretos para professores formados em programas de pós-graduação mais fechados e voltados para escolas de pensamento eurocêntricas. Os projetos de pesquisa e extensão desenvolvidos no campus costumam acompanhar esta abertura curricular, e buscam incentivar estudantes a se engajarem nos seus próprios temas de interesse, muitas vezes ligados aos contextos africanos e do Recôncavo.

\section{Unilab Quilombola}

Desde o ano de 2017, a Unilab se ampara em uma política de inclusão dos povos quilombolas e indígenas no Brasil mediante editais de preenchimento das vagas ociosas. Essa agenda é decorrência de um histórico de interdição a estes coletivos dos espaços universitários hegemônicos, seguindo uma tendência de outras universidades no Brasil. De lá pra cá, 206 quilombolas e 88 indígenas ingressaram nos cursos da Unilab na Bahia e no Ceará, conjugando ao projeto de internacionalização o fortalecimento da interiorização com ênfase nos povos e comunidades tradicionais.

No campus dos Malês, 156 quilombolas ingressaram via editais especiais, pertencentes a oito comunidades quilombolas em grande parte localizadas no Recôncavo: como Dom João e Monte Recôncavo (São Francisco do Conde), São Brás e Acupe (Santo Amaro), e Santiago do Iguape (Cachoeira). Além destas, estudantes de comunidades do Baixo Sul Baiano (Jatimane) e da Chapada da Diamantina completam os quadros discentes quilombolas, além de um estudante indígena do povo Kaimbé (Bahia). Além dos quilombolas discentes, há também uma docen-
11 A racialização do currículo tem emergido como um vocabulário que busca evidenciar e contestar estruturas universitárias e epistemologias eurocêntricas (Araújo; Maeso, 2019). No ano de 2014, a Rede dos Estudantes Negros e das Minorias Étnicas (Black \& Minority Ethnic Students' Network), da Universidade de Londres, lançou a campanha, "Por que razão o meu currículo é branco?”. Também, na África do Sul, o movimento "Rhodes deve cair" (Rhodes must fall), que levou à derrubada da estátua do imperialista britânico, Cecil Rhodes, do campus da Universidade da Cidade do Cabo, deu início a um amplo debate nacional sobre os mecanismos de acesso ao ensino superior, o racismo institucional das universidades e os possíveis caminhos para a descolonização do conhecimento acadêmico (Mbembe, 2016). 
te quilombola da comunidade de Santiago do Iguape, Zelinda dos Santos Barros, cientista social de referência importante no debate sobre a educação para as relações étnico-raciais (Barros et al., 2013).

No Recôncavo existem 31 comunidades quilombolas autodeclaradas junto à Fundação Cultural Palmares (Carvalho; Fernandes, 2019) que vêm se engajando numa frente ampla de demandas coletivas indissociadas do debate fundiário, socioambiental e da luta pelos territórios pesqueiros (Zagatto, 2011; Santos, 2017). Em São Francisco do Conde, o quilombo Dom João figura como uma importante referência de luta pelos direitos quilombolas, justamente por conjugar duas situações radicais de conflitualidade: a exclusão fundiária e o racismo ambiental derivados da história da produção canavieira e da exploração petroleira em seu território. Pelo fato de estar vizinho à Unilab e agregar uma série de atividades pedagógicas fomentadas por docentes e discentes, traremos Dom João como referência para descrever tanto aspectos caros ao contexto quilombola na região quanto experiências educativas vinculadas à universidade. Para tal, nos valeremos da análise de um Trabalho de Conclusão de Curso (TCC) sobre/em Dom João, e da descrição de algumas atividades pedagógicas no território.

\section{Histórias em Ruínas e Diásporas Internas}

Em 2 de setembro de 2019, Dom João sediava a defesa do TCC de Naiane Jesus Pinto, estudante do curso de Licenciatura em Ciências Sociais da Unilab. Naiane apresentava para a banca examinadora e moradores locais sua proposta de "escrevivência" a partir do relato sobre a trajetória de sua família, expulsa daquele mesmo quilombo um ano antes de nascer (Pinto, 2019). Passados mais de trinta anos da expulsão, era a primeira vez que membros de sua família retornavam ao local. Por isso, a presença dos parentes no ritual implicava uma espécie de retorno simbólico a um lugar originário interditado.

Com o trabalho, Naiane associava o ocorrido com sua família ao que chamou de "diáspora interna": conceito operativo para abarcar processos de precariedade habitacional e insegurança fundiária que obriga aos deslocamentos forçados a população negra no Brasil. Nesse sentido, Naiane buscava deslocar as reflexões da diáspora negra, comumente pensadas para conceituar fenômenos de deslocamento transatlântico, para a dimensão nacional e específica do Recôncavo. A estudante oferecia um elemento importante para refletir sobre processos de violência e resistência de longa duração ligados a Dom João, este lugar de onde é possível contar elementos da história da região vinculados às plantations canavieiras e à exploração petroleira em suas diferentes dimensões e temporalidades.

Algo em torno de 130 anos antes da defesa de Naiane, em 12 de maio de 1888, o Engenho Dom João figurava como um dos mais importantes do Recôncavo Baiano, lugar de cativeiro para 38 seres humanos escravizados. Tendo seu conjunto de casa grande, casa de moendas, instalações para o fabrico do açúcar, gado e áreas de canavial localizadas nas encostas de um manguezal entrecortado por rios com 
acesso à Baía de Todos os Santos, o lugar era estratégico para o transporte de produtos e pessoas, compondo as dinâmicas próprias de uma região que figurou como um dos centros brasileiros mais importantes da história da economia colonial açucareira nas Américas (Barickman, 1988; Amorim, 2008).

Diferente de outras regiões produtoras de açúcar, a transição do trabalho escravo para o livre não ocorreu de forma gradual no Recôncavo, implicando drasticamente no declínio e no colapso da produção baseada nos engenhos, bem como na permanência da condição escrava na véspera da abolição, como era o caso em Dom João. O lugar permaneceu com a produção açucareira, acompanhando as transformações tecnológicas e socioeconômicas derivadas, sobretudo, do aparecimento das Usinas nas primeiras décadas do século XX, que mantiveram algumas continuidades com as formas do trabalho colonial-escravista (Costa Pinto, 1998). Uma delas foi a manutenção da mão de obra dentro das fazendas, cujas famílias, em boa medida descendentes dos escravizados nos engenhos, eram, simultaneamente, moradores/trabalhadores, o que as colocava em uma condição de vulnerabilidade trabalhista e fundiária regida pelos laços assimétricos de apadrinhamento e patronagem.

A desativação da usina em 1969 e a negociação das terras com novos proprietários trouxeram implicações para parte das famílias que ali vivia, e que foram expulsas nos anos 1980 e 2000 a partir da articulação de fazendeiros locais com os políticos da cidade (Amorim, 2008; Pinto, 2016). A diáspora interna continuou em Dom João. De 2010 a 2014, a prefeitura municipal iniciou um novo processo de reintegração de posse, determinando, em cinco ocasiões diferentes, o despejo das famílias e a destruição de residências mediante tratores, a incluir dois terreiros de candomblé12 (Moreira et al., 2014). Nesse cenário de guerra ocorrido no contexto do próprio estabelecimento do campus dos Malês na cidade, nasce a luta quilombola em Dom João, para interromper os ciclos de exploração e expropriação inerentes ao lugar.

Essa luta ganha corpo no contexto de fortalecimento dos direitos quilombolas desdobrados da Constituição Federal de 1988, a partir da interlocução dos moradores de Dom João com uma rede ampla de comunidades quilombolas, pesqueiras e tradicionais do Recôncavo e do Brasil, incluindo aliados dos movimentos sociais e universidades ${ }^{13}$. É justamente um ano após um cenário de tensionamento radical da prefeitura com a derrubada das casas entre 2010 e 2014 que o campus dos Malês chega ao local, estabelecendo-se nas encostas do manguezal contínuas ao território quilombola. Com isso, a universidade passa a vincular-se e ser vinculada a uma agenda dos direitos quilombolas fomentada, também, pelos próprios quilombolas, que, aos poucos, foram ingressando na Universidade.

Há, portanto, uma aproximação não somente geográfica, mas temporal e existencial entre o estabelecimento do campus dos Malês e o fortalecimento de uma agenda quilombola em Dom João. Ambos, a seus modos, experimentaram processos de precarização e construíram, a partir deles, engajamentos compartilhados. Esta agenda está voltada não somente para o debate fundiário, antirracista e de valorização da cultura africana e afro-brasileira, mas também socioambiental,
12 A prefeitura municipal judicializou o processo de demarcação do território aberto pela comunidade junto ao INCRA no ano de 2013.

13 selho Pastoral da Pesca (CPP), o Movimento dos Pescadores Artesanais da Bahia (MPP) e os grupos de pesquisa Geografar/ UFBA, Giepem/UNILAB e Munzuá/UNILAB. 
tendo em vista que os moradores de Dom João são diretamente impactados pelas infraestruturas petrolíferas instaladas em seu território.

Remetido à história do açúcar, Dom João foi o nome da primeira base de exploração do petróleo para fins comerciais no Brasil, o campo Dom João, inaugurado em 1947 (BRITO, 2008). Foi a descoberta deste campo que reconfigurou o planejamento territorial da região, influenciando a construção de um dos polos petroquímicos mais importantes da América do Sul, a refinaria Landulpho Alves, erguida em 1950 sobre as áreas de manguezal na porção sudeste do município.

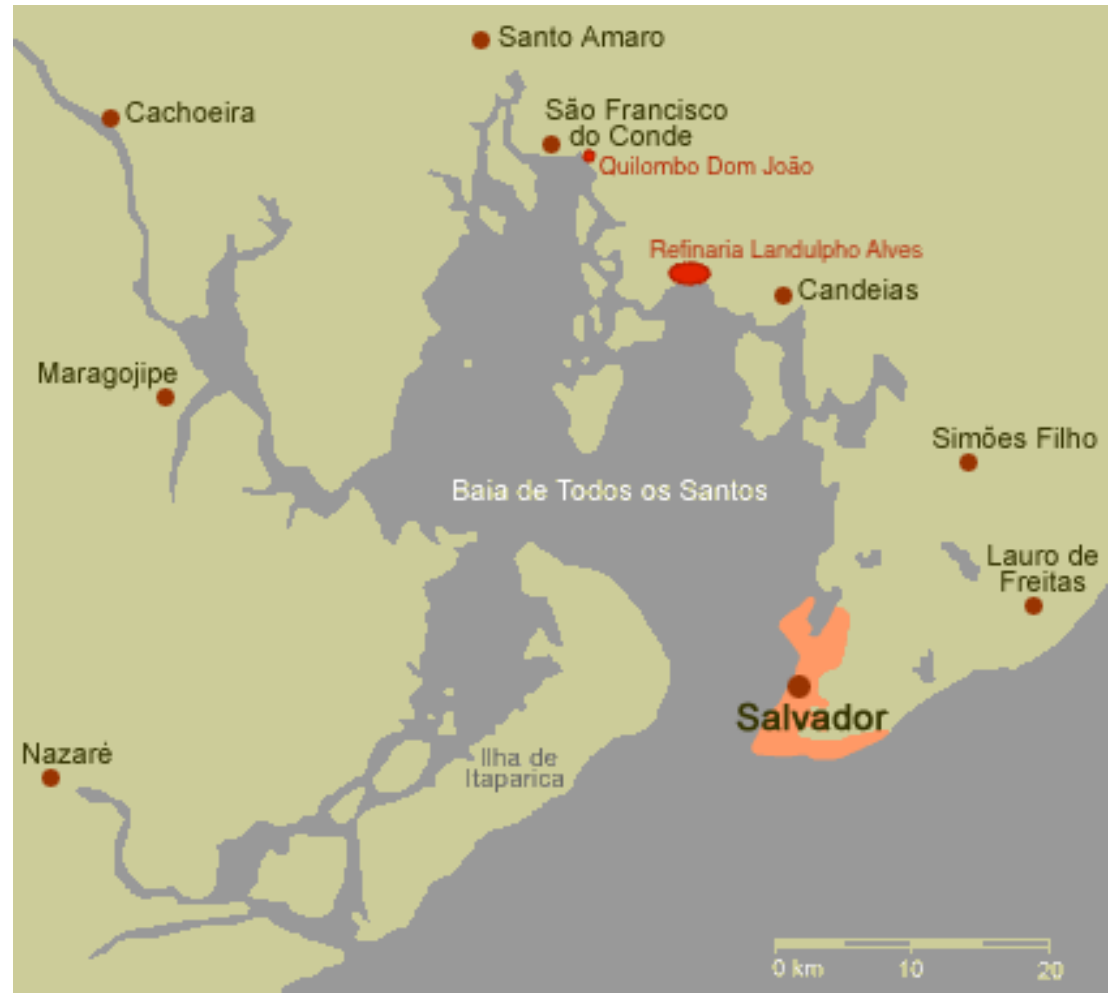

Por isso, a cidade responde por um dos maiores PIBs per capita do subcontinente, destacando-se em 2019 como o sétimo do país e o maior da Bahia (IBGE, 2019). A exorbitante arrecadação municipal não se converteu na melhoria da qualidade de vida dos franciscanos. Mesmo com a abundância do "ouro negro", a população continuou marcada pela pobreza e precariedade, apresentando baixo IDH e um dos mais elevados índices de concentração fundiária do Estado (Sansone, 2005; Geografar, 2015).

Pela presença da cadeia petrolífera nacional, as paisagens de manguezal da cidade são marcadas pelas infraestruturas industriais do petróleo: aterros, ruínas, manguezais mortos, tubulações, bases ativadas e desativadas, gases, trabalhadores, conformam os lugares e as habitabilidades nos territórios pesqueiros (Buti, 2020; Silveira; Buti, 2020). Por isso, além de remetidas à história do açúcar e da fazenda, as paisagens de Dom João também inscrevem a história do petróleo, e com ela outras formas de precarização da vida. Embora nem todas estejam em funcionamento, essas infraestruturas continuam nos lugares: as ruínas do ancoradouro, as vigas da caldeira da refinaria de petróleo, a chaminé da usina, o cimento da
Figura 1 - Esquema com localização dos principais centros urbanos do Recôncavo Baiano. Destaque para o quilombo Dom João e a Refinaria Landulpho Alves, no município de São Francisco do Conde. Adaptado.

Fonte: http://schwarzegoetter-im-exil.de/eng/ glossar/map/baia.html. Acesso em: 04 jul. 2020. 
lavagem de caminhão, compõem os ambientes das casas, quintais e áreas de sociabilidade e trabalho das aproximadamente 80 famílias que ali vivem.

Habitar as ruínas do açúcar e do petróleo é a condição quilombola do lugar. $\mathrm{O}$ que implica existir nas paisagens conformadas pelas cercas das fazendas e pela contaminação das indústrias. Por isso, a agenda de direitos fomentada pela comunidade tem implicado, na Unilab, um debate sobre desigualdade fundiária e racismo ambiental. Essa é a agenda principal engajada pelas lideranças dos movimentos pesqueiros e quilombolas da Bahia, que simultaneamente lutam contra dois inimigos históricos: as interdições impostas pelas figuras clássicas do poder senhorial (os fazendeiros), e o racismo e o sacrifício ambiental derivados das contaminações industriais produzidas por "assassinos invisíveis" ${ }^{14}$.

\section{Aprender nos territórios}

O TCC de Naiane acima comentado foi desdobramento de uma atividade pedagógica no território de Dom João para o curso de Licenciatura em Pedagogia, que consistia em caminhar por alguns lugares, compartilhar momentos com os moradores e ali pernoitar ${ }^{15}$. Durante uma dessas caminhadas em direção ao bueiro da usina de açúcar, local antigo de moradia da sua família, Naiane afirmou "que as ruínas pareciam comunicar algo", o que lhe permitia dialogar com o "território falante" em "forma de vibração" e "arrepio" (PINTO, 2019). A pesquisa estabelecia, com o território, um diálogo cosmosensorial.

Atividades como as descritas por Naiane estão presentes na Unilab. Elas evidenciam ações inovadoras que extrapolam os espaços da sala de aula para incorporar os territórios e perspectivas locais nos planos de ensino. A inspiração para o desenvolvimento das propostas guia-se por alguns engajamentos comunitários na produção de dinâmicas que podem ser entendidas como ecopedagógicas ${ }^{16}(\mathrm{Gu}-$ tierrez; Prado 1999; Gadotti, 2001). Nelas, comunidades têm produzido vivências sobre aspectos de sua vida e história a partir de um roteiro de navegação nos ambientes, relegando ao que chamamos de "natureza" um importante índice de referencialidade da "cultura".

Produzidas por comunidades quilombolas da região, essas dinâmicas têm dimensão socioambiental e se dão como forma de valorizar o grupo, reforçar direitos territoriais, fomentar a economia sustentável local e denunciar conflitos e problemas vividos. A seguir, serão comentadas duas atividades desenvolvidas em Dom João que buscaram explorar a problemática do petróleo a partir da perspectiva quilombola em seus territórios de vida, nos permitindo uma abordagem diferente daquela oferecida pelos funcionários da Refinaria Landulpho Alves durante a "visita técnica" ao enclave petrolífero.

A primeira delas ocorreu em 12 de maio de 2018, como desdobramento das atividades para o curso de Licenciatura em Ciências Sociais ${ }^{17}$. Ela consistiu em um roteiro de caminhada que ligava o campus dos Malês à "trincheira do Marapé”, nome dado a uma base de exploração do petróleo localizada no manguezal ho-
14 A noção de racismo e sacrifício ambiental, bem como de assassino invisível, tem sido vocalizada pelas mulheres marisqueiras e lideranças quilombolas da Baía de Todos os Santos, como Eliete Paraguassú, Marizelia Lopes, Joselita Gonçalves e Elionice Sacramento. Sobre o tema, ver: https://midianinja.org/news/ assassino-invisivel-lixo-industrial-na-ilha-de-mare-chega-a-niveis-mortais/. Acesso em: 07 jul. 2020.

15 Atividade organizada pela professora Eliane Costa Santos para a disciplina "Educação Quilombola".

16 A Ecopedagogia, ou Pedagogia da Terra, é um movimento pedagógico com origem na educação problematizadora de Paulo Freire, atuando na “promoção da aprendizagem do sentido das coisas a partir da vida cotidiana" (Gadotti, 2001, p. 89).

17 Atividade realizada por Rafael Buti para a disciplina "Território e Identidade". 
mônimo próximo à Unilab. Foi o Sr. Zé, pescador quilombola de Dom João, quem guiou a turma no que se convencionou chamar de caminhaula. A data escolhida não foi aleatória: ela antecedia o 13 de maio, e com isso buscava refletir sobre discriminação racial. A intenção com a vivência foi produzir uma experiência sobre o racismo ambiental com foco nos modos de habitar e resistir das comunidades quilombolas e pesqueiras da cidade diante dos efeitos da cadeia petrolífera nas paisagens de manguezal. Por isso, no trajeto, Sr. Zé ensinava desde referências da territorialidade local, mostrando lugares de despacho do candomblé e árvores frutíferas, a técnicas de pesca e de ocorrência dos caranguejos, bem como os efeitos perturbadores da cadeia petrolífera, indicando as ocorrências de aterro, ruínas, mangues mortos, tubulações defeituosas e outras formas de precarização.

A intenção era que no dia 17 fizéssemos uma dinâmica da turma em sala de aula com a presença de Sr. Zé, para que pudéssemos relatar as experiências e buscar, coletivamente, soluções para os problemas mapeados. Qual não foi a surpresa quando, naquela mesma data, Dom João amanheceu com parte de sua área de manguezal atingida por um vazamento grande de petróleo, ocorrido pelo rompimento, no dia anterior, de um duto que ligava justamente a trincheira de Marapé a um reservatório próximo. Naquele dia, em lugar de pescadores e marisqueiras no manguezal, homens e caminhões da Petrobrás trabalhavam para contornar o desastre, impedindo, inclusive, a aproximação dos moradores.

Como desdobramento do ocorrido, a turma, reunida com o Sr. Zé no dia 17, propôs a organização de uma caminhada ao território contaminado, prevendo, no trajeto, uma visita à sede da Defesa Civil para cobrar soluções. Realizado no dia 25 de maio em colaboração com a Associação de Dom João sob o nome Tóxico-Tour Dom João, esta segunda caminhada se inspirou no Tóxico-Tour Ilha de Maré, atividade desenvolvida pelo quilombo da Ilha de Maré que consiste em produzir um tour aos lugares de vida comunitária perturbados pelos vazamentos e contaminações trazidas pelas águas do porto de Aratu e do Complexo petroquímico de Camaçari ${ }^{18}$. O objetivo do tóxico tour é produzir experiências de sensibilização nos territórios vinculando as finitudes impostas pela cadeia de exploração petroleira às dimensões da vida: por isso percorre-se desde paisagens contaminadas e devastadas a lugares de referencialidade do cotidiano e da história local, cujo desfecho é um banquete regado à culinária e musicalidade como formas de celebração.
18 O tóxico tour está vinculado à campanha antipetroleira Nenhum Poço a Mais. Disponível em: https://areaslivresdepetroleo.org/. Acesso em: 2 maio 2020. 


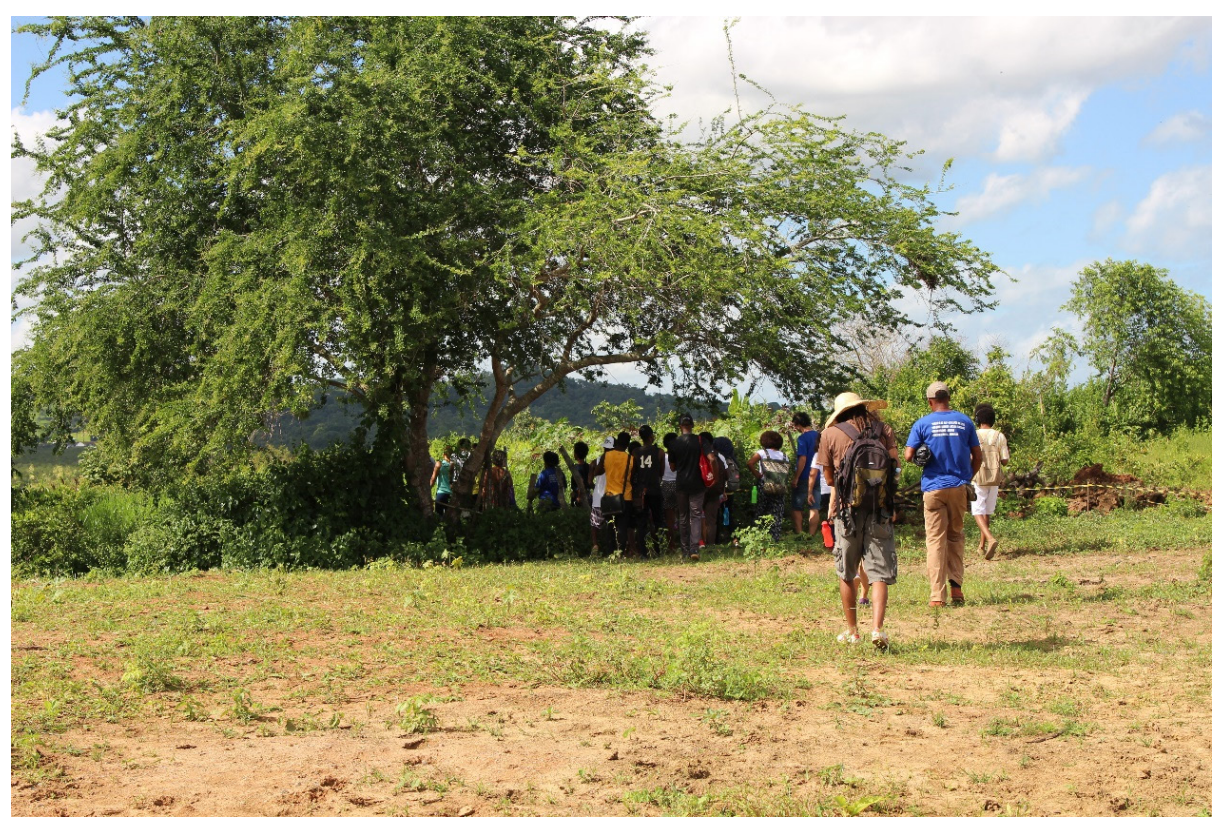

Inspirados na proposta da Ilha de Maré, engajamos em Dom João um tour nos lugares contaminados pelo vazamento, onde estudantes internacionais e nacionais puderam conhecer os efeitos imediatos da vazão (visuais, sonoros, táteis, olfativos) ao percorrerem os rastros deixados pelo petróleo. A atividade serviu, também, para solicitar à Defesa Civil do município medidas de reparação aos danos causados, desdobrando-se em uma carta aberta escrita pela associação quilombola em colaboração com grupos parceiros em defesa dos territórios pesqueiros (Associação Quilombola Dom João, 2018).

Podemos considerar as abordagens ecopedagógicas aqui descritas como efeito da democratização da universidade pública nos interiores do Brasil, e da reverberação da diversidade de saberes nas experiências educacionais. Elas parecem jogar com três dimensões importantes enfatizadas por Tim Ingold (2002; 2015). A primeira, de que as histórias estão imersas no mundo, e que devemos devotar às paisagens um lugar privilegiado de referencialidade social; a segunda, que caminhadas são importantes recursos metodológicos historicamente negligenciados pela pesquisa, havendo dimensões da vida que só podem ser percebidas e produzidas no movimento; e por fim, a terceira, que a educação é um exercício de atentividade, o que impõe ao processo de aprendizagem a necessidade da experiência compartilhada.

$\mathrm{Na}$ Unilab, as experiências são compartilhadas por gente dos dois lados do Atlântico, como Naiane, nascida em São Francisco do Conde, e como Galileu Indi, guineense que esteve presente no tóxico tour e está matriculado na universidade desde 2017. Durante a caminhada, Galileu foi perguntado pelo cinegrafista que cobria o evento o que esperava encontrar no Brasil antes de aqui chegar. Assim respondeu:
Foto 1 - Caminhos percorridos no Tóxico Tour Dom João. Fonte: Proext/ Unilab 
de dois tipos de Brasil, o Brasil da metrópole, e outro tipo de Brasil como este aqui, mas sempre colocava minha visão, minha pessoa, num Brasil diferente desse. Portanto, meu apelo aqui é pedir ao governo federal que pensasse em um outro tipo de Brasil. Populações vivendo nesse tipo de situação é um pouco difícil, um pouco difícil, precisamos pensar num outro tipo de Brasil.

O relato revela o estranhamento de um estudante internacional no interior do Brasil diante de uma situação lida como surpreendente. Seu sentimento de injustiça perante uma paisagem perturbada e seu questionamento sincero às autoridades para que tomem providências na construção de um "outro tipo de Brasil" são efeitos das experiências vividas na Unilab. Como Galileu, há outros estudantes internacionais trazidos para este lado do Atlântico que refletem sobre os estranhamentos de se aportar em um Brasil não imaginado.

\section{Alteridades africanas, estranhamentos franciscanos}

Nos Malês, a internacionalização do ensino superior se manifesta principalmente na presença dos estudantes estrangeiros. Resultado de acordos de cooperação internacional no campo da educação, esta presença justifica e fortalece o tipo de currículo ofertado, sensível a temáticas além-fronteiras, sobretudo aquelas voltadas ao campo dos estudos africanos, da diáspora e das relações étnico-raciais. Além disso, esta imigração temporária altera o ambiente local, introduzindo novas línguas, outros conhecimentos e estilos de vida no cotidiano universitário e da cidade.

No campus impera uma postura xenofílica em relação às pessoas, coisas e ideias provindas de África. Mas em São Francisco do Conde a recepção dos estudantes africanos tende a ser mais difícil. Tal fenômeno não é específico da cidade e já foi registrado em outros momentos e lugares do país (Reis, 2010; Langa, 2012; Silva; Moraes, 2015), de modo que a discriminação sofrida por estes estudantes opera numa dupla chave do racismo estrutural: eles são pessoas negras e também estrangeiros de África. As dificuldades vividas pelos estudantes internacionais em São Francisco do Conde são temas recorrentes nos debates universitários, inclusive nos Trabalhos de Conclusão de Curso (TCCs). Nesta seção destacamos algumas destas conflitualidades mobilizando para isso as pesquisas desenvolvidas pelos próprios discentes. Nossa ênfase volta-se mais para as tensões e os estranhamentos produzidos no jogo das alteridades estrangeiras, o que não esgota outras leituras possíveis dedicadas às cumplicidades e identidades ali estabelecidas.

Ao saírem de seus países de origem, os estudantes levam consigo seus passaportes e estatutos específicos de cidadania, mas ao chegarem à Unilab são transformados e se redescobrem como "africanos". Esta titulação é reforçada pelo tipo de tratamento burocrático uniforme oferecido a eles na instituição, mas também é afirmada pela música e pela dança, pelo som e pelo gesto, formas culturais ex- 
pressivas por meio das quais os estudantes recriam e reinventam, fora de África, um sentido próprio e compartilhado de africanidade. Contudo, alguns estudantes criticam a generalidade desta categoria, assim como a própria centralidade dada, na Unilab, à "relação entre Brasil e África", questionando que "estes termos não deveriam ser tratados como equivalentes, o primeiro é um país, o segundo um continente inteiro". Seja como for, a categoria dos "estudantes africanos" engloba não apenas um coletivo multinacional associado aos PALOP ${ }^{19}$, mas também multilíngue e multiétnico, visto que alguns internacionais, principalmente os guineenses e angolanos, não abandonam suas identidades étnicas: são Fulas, Bijagós, Mandingas, Balantas, Manjacos, Papel, Ovimbundu, Herero, Bakongo, Ambundu, etc.

Os jovens que chegam para estudar no campus dos Malês não presenciaram as lutas de libertação em seus países, nem vivenciaram a formação dos Estados socialistas pós-coloniais que sucederam ao império ultramarino português. Estes estudantes fazem parte de uma geração que cresceu já na era da globalização neoliberal do pós-Guerra Fria, contexto no qual os heróis da independência ainda são cantados como idealizadores da modernização nacional africana, mas esta parece ter sido abandonada em favor das elites urbanas, mais próximas dos circuitos do capital transnacional que da realidade camponesa e de pobreza em que vive parte considerável de seus conterrâneos. Neste sentido, os custos da viagem, de responsabilidade dos estudantes, assim como a divulgação dos processos seletivos nos países parceiros, ainda centrada nas embaixadas brasileiras das capitais dos PALOP, são fatores que reforçam a exclusão dos candidatos africanos que vivem no interior rural de seus países.

As pesquisas desenvolvidas pelos discentes dos Malês sobre a imigração estudantil mostram que, via de regra, a chegada em São Francisco do Conde é percebida pelos internacionais como um processo custoso. Eles saem de casa por motivos diversos, muitas vezes devido 1) às dificuldades de continuarem o ensino superior por lá, 2) à instabilidade política e econômica de seus países, 3) à oportunidade de estudarem fora e 4) ao interesse no projeto curricular da Unilab. Como Margarida Bendo (2016) e Casimiro Ié (2016) identificaram em suas pesquisas, os estudantes viajam para o Brasil sensibilizados pelas globalizadas e festivas imagens da democracia racial, projetadas no futebol, no carnaval e nas novelas, que retratam um país bonito e idealizado como um cartão-postal, mas ao chegarem para viver numa cidade pobre e pequena do interior da Bahia, suas expectativas são estilhaçadas.

Como já descrito, São Francisco do Conde concentra de modo particular a sobreposição histórica da economia de duas importantes commodities regionais: o açúcar e o petróleo. Na paisagem urbana, fragmentos do barroco colonial - igrejas setecentistas, sobrados portugueses e palmeiras imperiais - estão embebidos por um vasto urbanismo popular e informal, com casas de autoconstrução em aglomerações sem planejamento, ruelas irregulares e uma complicada trama de fiações elétricas e "gatos". A cidade possui pouco saneamento básico e os rejeitos urbanos deságuam na Baía de Todos os Santos, onde pescadores, marisqueiros
19 Um coletivo multinacional assimétrico, visto que dos 282 estudantes africanos matriculados no primeiro semestre de 2020 nos Malês, 169 eram guineenses, 92 angolanos, 9 são-tomenses, 9 caboverdianos e apenas 3 moçambicanos. 
e catadores de caranguejos e guaiamuns exercem seu ofício. É verdade que a exploração do petróleo gerou alguma oferta de emprego na cidade, com melhores salários no início, mas acabou aumentando a dependência econômica voltada ao setor, transformando a prefeitura na principal fonte de contratação local, atrofiando outras formas de investimento público e trabalho, principalmente na produção agrícola (SANTANA, 2011). Com a queda internacional do preço dos hidrocarbonetos (iniciada com a crise de 2008), o desmonte da Petrobrás e a recente venda da Refinaria Landulpho Alves, a receita municipal decresceu sensivelmente, aumentando o desemprego local e a insegurança, e elevando as expectativas dos moradores locais em conseguir novos rendimentos a partir da presença da Unilab e dos estudantes internacionais.

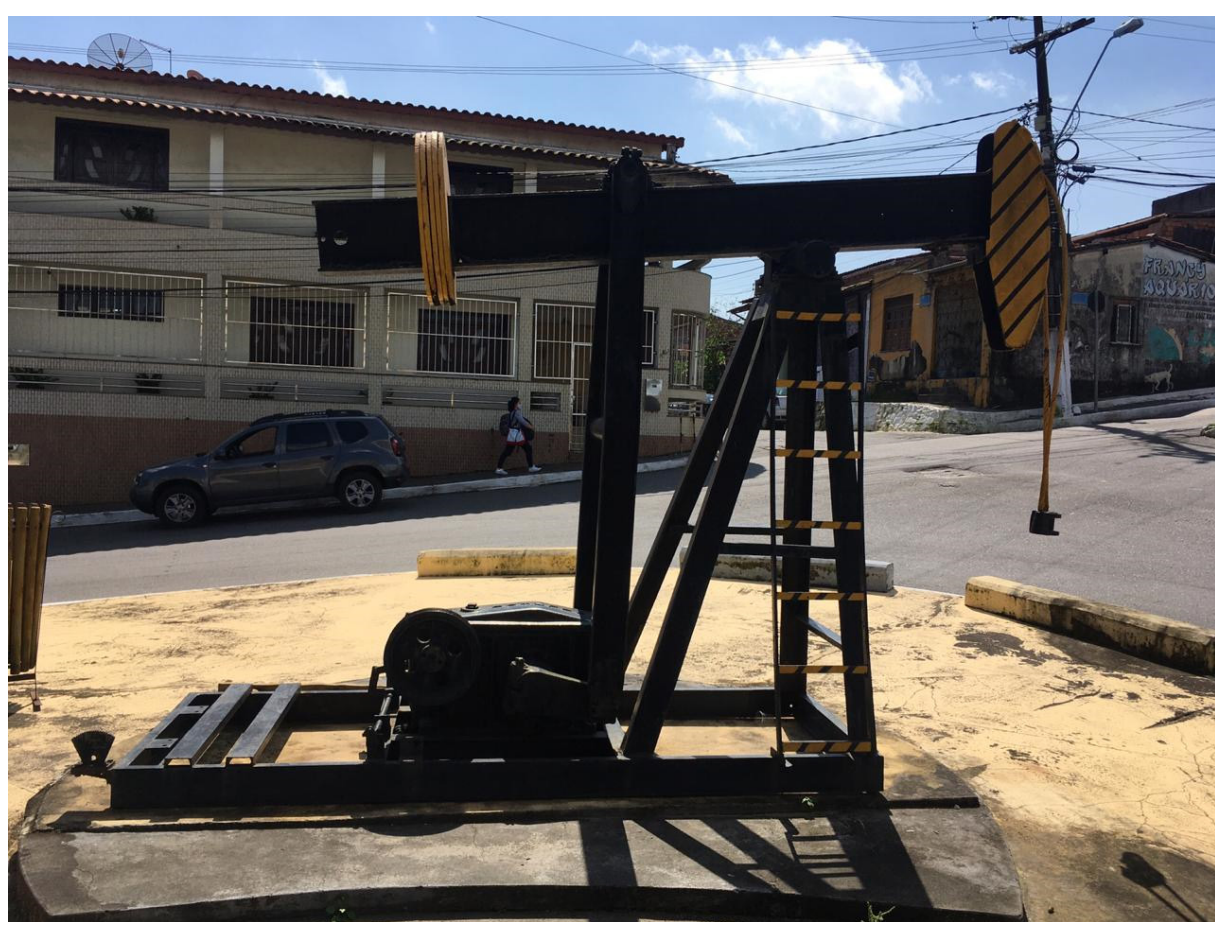

Contudo, estes mesmos estudantes reclamam da dificuldade em encontrar uma casa para morar e em negociar um bom preço pelo aluguel na cidade. São frequentes as reclamações de que "as casas sempre estão em mau estado", "falta água" e "são muito úmidas", e de que "os proprietários não confiam nos africanos" e "cobram muito caro". Neste sentido, o estudo de Júlio Cam-Nate Sumba (2019) revelou que a presença da Unilab aumentou os valores do mercado informal de aluguéis na cidade. Com a escassez de imóveis adequados e os preços exorbitantes de locação, a solução foi coabitar, em grupos de 3 a 6 estudantes, um mesmo imóvel, partilhando cômodos a fim de poder economizar a bolsa-auxílio de 530 reais que recebem do governo brasileiro como parte da política de permanência estudantil na Unilab.

Ainda que reduzida, esta bolsa-auxílio também provoca tensões no interior do campus. Alguns estudantes brasileiros afirmam que os internacionais são privilegiados em detrimento dos nacionais, quase sempre pessoas negras e pobres, e que não possuem bolsas daquele tipo. Além disso, boatos circularam na cidade
Foto 2 - Monumento à exploração do petróleo: réplica de bomba de sucção exibida como patrimônio em São Francisco do Conde. Fonte: Foto dos autores. 
dizendo que os internacionais receberiam auxílios entre 3 e 4 mil reais do governo. Estes rumores tornaram ainda mais difícil a inserção destes estudantes, fortalecendo a ideia de que "os estrangeiros têm dinheiro", tornando-os alvo de roubos e estimulando o aumento dos preços dos aluguéis e também dos produtos nos mercadinhos da cidade. De fato, quando da criação do campus dos Malês, o município não foi preparado em termos de infraestrutura para receber novos moradores de fora, tampouco houve uma campanha de sensibilização explicando aos franciscanos sobre a vinda dos africanos e o projeto da universidade. Sobre isso, uma moradora chegou a lamentar, para um dos autores deste artigo, ser "uma grande pena que a Unilab fosse só para os de África e não para os daqui”.

O desconhecimento sobre a universidade também acompanha o próprio desconhecimento que alguns franciscanos possuem sobre África. Na cidade é comum que os estudantes internacionais sejam chamados pela alcunha genérica de "angolanos", uma designação definitivamente incômoda, quando não ofensiva, para eles. Como relatou Amadu Bedam em sua monografia, as questões que os moradores locais fazem aos estudantes frequentemente explicitam suas visões sobre o continente: "você já viu leão? Dorme nas árvores? Há carros na África? Sabes andar de bicicleta?” (Bedam, 2017, p. 11). O tipo de acolhimento ofertado aos estudantes internacionais está, portanto, diretamente relacionado às representações negativas sobre a África e os africanos que circulam na sociedade anfitriã. E quando o acolhimento é percebido como muito hostil, pode ser definido na chave do "racismo xenofóbico que os franciscanos têm em relação aos africanos", como alunos já afirmaram em aula.

A própria experiência do racismo antinegro é uma questão nova para muitos internacionais recém-chegados, algo que os africanos aprendem ao saírem de seus países. Num programa televisivo da Rede Globo, o estudante santomense Lauro José explicou sobre a descoberta do preconceito racial ao chegar no Brasil.

Eu acho que esta é uma história bem comum mesmo entre todos nós africanos que viemos. Pelo menos nas telenovelas não se aborda muito sobre o assunto, então quando você sai de um contexto imagético e vem para um contexto corpóreo, físico, é totalmente diferente, você conviver e sentir na pele o que você não sentia em outro lugar. Então acaba sendo esta transição, e esta transição carrega dentro de si este aspecto racial. Você aqui, eu neste caso, sou visto como negro, sabendo que eu nunca problematizei esta situação em meu país, São Tomé e Príncipe, e passei a problematizar isso aqui ${ }^{20}$.

Se no Brasil "ser negro" é uma questão indissociada da problemática racial, em muitos países africanos, não. A travessia Atlântica faz com que eles sintam "na pele” tal realidade. Contudo, São Francisco do Conde é uma cidade majoritariamente negra e marcada por desigualdades raciais de longa duração. Ali, a diferença entre negros nacionais e internacionais é perceptível, sobretudo, na vestimenta e na linguagem, verbal e corporal, dos estudantes. Tal diferença funciona como
20 Episódio do programa Conversa com Bial, que também contou com a presença de Martinho da Vila e do prof. Marcos Carvalho, coordenador do projeto de extensão Bota Fala, da UNILAB, no qual se discutiu sobre o campus dos Malês. Disponível em: https://globoplay. globo.com/v/6249793/. Acesso em: 20 jun. 2020. 
um fator implícito de negociação nas trocas e sociabilidades cotidianas, incluindo as interações que envolvem religião.

Com a imigração estudantil, um grupo de muçulmanos nascidos na Guiné-Bissau se instalou na cidade e passou a se reunir para rezar e estudar o Alcorão e outros textos islâmicos. Abdulai Djabi, que integra o projeto de extensão de língua e cultura árabe da Unilab ${ }^{21}$, foi reconhecido por este grupo, e também pelo sheik Abdul Ahmad, nigeriano que conduz a Mesquita de Salvador, como imã (autoridade religiosa) da comunidade islâmica de São Francisco do Conde. Em sua monografia, Djabi (2017) analisou as dificuldades vividas pelos muçulmanos da Unilab: mulheres sentem receio de usar o véu em público para não serem chamadas de "mulher-bomba"; as cinco rezas diárias voltadas a Meca são dificultadas devido ao horário das aulas e à inviabilidade de se rezar em público na cidade; a alimentação também é complicada, nos restaurantes do campus e da cidade, tendo em conta a ausência de carne bovina halal e a oferta frequente de carnes suínas, proibidas, misturadas com outros alimentos típicos, como o feijão. Além disso, a ausência de uma mesquita em São Francisco do Conde também obriga o deslocamento frequente dos estudantes ao Centro Cultural Islâmico da Bahia. Esta circulação interurbana voltou a colocar em conexão, quase dois séculos depois da Revolta dos Malês, os afromuçulmanos do Recôncavo em contato com os da capital.

Parte destes constrangimentos religiosos também está relacionada às representações sobre o islã e os muçulmanos que circulam em São Francisco do Conde, onde a presença evangélica é forte e tem crescido rápido, acomodando-se ao lado das formas históricas do catolicismo popular e das religiões afro-brasileiras. Neste meio, narrativas orientalistas difundidas pela mídia e pelo noticiário internacional ensinam ao público que o "islã é violento" e "anticristão", estabelecendo associações imediatas entre muçulmanos e terroristas. Segundo Djabi (2017), é sobretudo com estas representações que os estudantes muçulmanos da Unilab têm de negociar cotidianamente, escondendo os sinais reconhecíveis daquilo que constituem sua fé (o véu e a reza pública), tendo de explicar permanentemente por que não consomem carnes e álcool, e barganhando publicamente os sentidos de uma religião quase sempre narrada nos termos da "guerra ao terror". Como relatou em tom de desabafo o estudante guineense Mussa Kymani, "é muito difícil viver em outro país sendo adepto de uma religião mundialmente odiada".

\section{Aprender nas fronteiras}

No campus dos Malês, a islamofobia é um dos temas debatidos nas aulas. No curso de Relações Internacionais, por vezes, estudantes reclamam que a religião "tem sido utilizada como justificativa para esconder outros interesses econômicos e políticos em jogo". Numa destas discussões mencionou-se o grupo militar Boko Haram como um exemplo, que estaria mobilizando o nome do islã como pretexto para controlar instalações petrolíferas na Nigéria. A associação entre a presença
21 O projeto é coordenado pela professora Lídia Lima da Silva. 
de recursos minerais e o suposto terrorismo islâmico também foi questionada em classe a partir dos eventos mais recentes do norte de Moçambique, onde a descoberta de grandes jazidas de gás e carvão transformou a região num campo de morte e conflito devido aos ataques de grupos armados autodenominados "jihadistas".

Nas aulas, as problemáticas associadas à guerra, ao autoritarismo e à dependência econômica podem ser trazidas pelos próprios estudantes internacionais através de suas memórias pessoais e familiares, cujas trajetórias se entrelaçam com histórias nacionais e regionais. Em alguns casos, as questões mais candentes levantadas pelos estudantes estão conectadas à "lógica da extração e da predação que caracterizam a economia política das matérias-primas na África” (Mbembe, 2019, p. 31). Os enclaves petrolíferos do continente africano são, por vezes, controlados por multinacionais para as quais o Estado subempreita, ou praticamente delega, sua soberania, às vezes em cumplicidade com formações armadas dissidentes, compondo um tipo de economia que simboliza a osmose da atividade mercantil e bélica, de extração de recursos naturais e exploração de vidas humanas. Também cenários conflagrados de disputa aberta pela riqueza mineral podem levar ao conflito armado e violento, como em Angola, o segundo maior país produtor de hidrocarbonetos da África Subsaariana. O petróleo teve papel central na longa e intermitente guerra civil angolana (1975-2002) e, ainda hoje, permanece fornecendo importantes rendimentos ao mesmo partido (MPLA) que se instalou no poder desde a independência (Penha, 2016).

Outros países dos PALOP, como São Tomé e Príncipe e Guiné Equatorial, também possuem reservas de hidrocarboneto e revelam alguns sintomas deletérios da "maldição do ouro negro" (MONIÉ, 2012). Por ora, o desenvolvimento do petróleo em São Tomé e Príncipe não é efetivo, já que as infraestruturas de exploração não foram instaladas. Ainda assim, a elite crioula local vem estabelecendo condições legais e de cooperação técnica internacional para se beneficiar do boom petrolífero, em detrimento da maioria da população insular que, até o fim do século XX, dependia fundamentalmente de uma economia de exportação açucareira de tipo plantation (SANGUIN, 2014). Por sua vez, a descoberta do petróleo no vizinho mar territorial de Guiné Equatorial, nos anos 1990, incentivou a exploração off-shore por empresas americanas, num sistema em que a renda gerada voltava-se para os interesses neopatrimonialistas da família de Teodoro Obiang, presidente no poder desde 1979, e não se traduziu em investimentos públicos para o desenvolvimento de um dos países mais pobres do mundo. Num processo contestado, em 2014, a CPLP acolheu a Guiné Equatorial, antiga colônia espanhola, na comunidade lusófona mediante vários condicionantes, entre estes, que o país deveria oficializar a língua portuguesa e abolir a pena de morte de sua constituição. Esta última promessa não foi cumprida e sua adesão à CPLP revelou outros interesses, sobretudo voltados ao fortalecimento da cooperação no setor energético entre países produtores de petróleo, entre os quais Brasil e Timor-Leste também se destacam (Sá, 2015-2016).

Justamente por serem muito distintos e distantes, estes contrapontos internacionais permitem reflexões interessantes e alternativas nas práticas de ensino e 
pesquisa universitária, abrindo novos questionamentos a respeito das dinâmicas que envolvem a presença do combustível fóssil no Recôncavo Baiano, tal como o rentismo e a petrodependência, o pouco rigor e transparência no uso dos royalties, o clientelismo, a exclusão da população local e o grande impacto ambiental na região. Seja o pré-sal da costa brasileira ou os novos campos de exploração no Golfo da Guiné, as recentes descobertas de jazidas de petróleo nas margens do Atlântico Sul não apenas fortaleceram a histórica posição da América do Sul e da África como zonas exportadoras de produtos primários na economia global, mas também modificaram a geopolítica regional, reconfigurando o campo de ação das comunidades, cidades e Estados ribeirinhos, e despertando interesse das corporações multinacionais do setor e das grandes potências consumidoras de petróleo, como Estados Unidos e China (Góes; Silva, 2017). Tais movimentações recolocam a necessidade de se examinarem criticamente as consequências ambientais e humanas das infraestruturas e disputas petrolíferas neste espaço oceânico. Foi com estas e outras questões em mente que acompanhamos os estudantes à Refinaria Landulpho Alves-Mataripe, tal como descrito na introdução do artigo.

A situação dos estudantes internacionais no campus dos Malês e São Francisco do Conde, ainda que imponha certos obstáculos, permite-lhes uma visão bifocal, atenta aos dois lados do Atlântico. Eles enxergam as coisas brasileiras com olhos africanos e gradativamente aprendem a ver as coisas africanas também com olhos brasileiros. Neste deslocamento, estudantes africanos desprovincializam-se, mas principalmente ajudam a desprovincializar seus anfitriões ao lhes apresentarem novos problemas e perspectivas, também novos modos de pensar, falar e fazer. A imigração estudantil é, portanto, uma forma de educação transfronteiriça e intercultural, na qual os dois lados que participam do encontro internacional aprendem com a diferença. Contudo, as condições para que esta educação cosmopolita ocorra são muito mais duras e difíceis para aqueles que vêm do exterior.

\section{Malês Resiste!}

Neste artigo interrogamos dimensões do processo de interiorização e internacionalização da Unilab no Recôncavo Baiano, considerando a experiência quilombola e africana no território e suas possíveis relações com o petróleo. Duas vivências educativas aqui trazidas são elucidativas destas relações: a "visita técnica" à refinaria Landulpho Alves-Mataripe (RLAM) e as caminhadas nos territórios pesqueiros nos manguezais. O primeiro espaço constitui um enclave fortificado, principal centro de comando da cadeia de exploração de hidrocarbonetos na região, por isso mesmo um lugar isolado em relação à paisagem circundante, também vigiado em relação à circulação de discursos e informações difundidas. Por sua vez, o mangue é um espaço aberto à interlocução diversa, com pescadores quilombolas e outros seres vivos, e permite formas inusitadas de aprendizado quando tomado a partir de uma proposta de ensino experimental e em movimento. São dois postos de observação diferenciados, um controlado e outro não, 
a partir dos quais é possível compreender as dinâmicas do petróleo numa escala mais ampliada, considerando a multiplicidade dos corpos, espaços e problemas enredados, assim como algumas de suas consequências deletérias, a deterioração do ambiente e das formas de vida, e os ininterruptos esforços institucionais para silenciar a destruição em curso.

Ao mesmo tempo em que o petróleo estabelece uma territorialização própria no Recôncavo, ele também se realiza no âmbito internacional. No caso da Unilab, este movimento de interiorização e internacionalização foi considerado a partir da experiência do quilombo Dom João e dos estudantes africanos em São Francisco do Conde. As formas de aprendizado no território e nas fronteiras, tal como foram aqui discutidas, permitem visões mais sensíveis aos fenômenos locais e globais, estabelecendo relações de semelhança e diferença entre as realidades interiores e exteriores que os constituem. São práticas universitárias que focalizaram sobre as dinâmicas do Atlântico Sul, pensado tanto como um espaço de intercâmbio no qual o campus se situa quanto uma zona de entroncamento na qual as questões da identidade negra cruzam os dilemas envolvidos com o ouro negro. Estes processos voltados para dentro e para fora confluem e se reúnem nos Malês, ele mesmo um microcosmo no qual se entrelaçam diversos fios e pontos da diáspora afro-atlântica, projetada a partir de diferentes lugares e histórias de engajamento, luta e encontro.

Neste sentido, diferentes configurações diaspóricas foram aqui consideradas, de modos articulados e sobrepostos. Além do histórico tráfico de escravizados, que durante séculos conectou as duas margens oceânicas, destacamos a existência de uma "diáspora interna" associada ao deslocamento de famílias expulsas de seus lares na luta pela terra quilombola no Recôncavo Baiano, assim como discutimos a experiência de imigração temporária estudantil daqueles africanos que cruzaram fronteiras e passaram a habitar a cidade de São Francisco do Conde. São modalidades de dispersão e separação que compartilham experiências diferenciadas de extroversão com a terra.

Estes movimentos também revelaram faces do racismo antinegro e outras modalidades de intolerância e hostilidade racial, como o racismo ambiental, a xenofobia e a islamofobia. Estas formas de violência, vividas e problematizadas pelos próprios estudantes, em suas reflexões e pesquisas, evidenciam tanto os desafios de um projeto de cooperação internacional voltado à África nos interiores do Brasil, quanto o necessário compromisso institucional de uma universidade empenhada na promoção da igualdade racial e que busca formar quadros qualificados em pesquisa e ensino de história e cultura africana e afro-brasileira.

Os Malês constituem, por isso, um microssistema de hibridez linguística e religiosa, política e acadêmica, que aproxima pessoas e conecta multilocalidades. Ali ocorrem, de forma inovadora, intensas experiências e experimentações universitárias que vinculam a cooperação internacional no campo da educação às práticas de envolvimento com os problemas da terra e do entorno local. O pequeno campus fora de sede da Unilab é, assim, um lugar de encontro que reverbera para além de suas precárias e temporárias estruturas físicas. A tragédia de seu abandono insti- 
tucional e material não impede a experimentação de práticas inovadoras e ideias radicais no campo da educação superior e das Ciências Humanas. Ali, estudantes africanos, como o guineense Galileu Indi, descobrem um Brasil não imaginado no interior da Bahia, se interessam pela vida e luta quilombola e clamam por um "outro tipo de Brasil", enquanto quilombolas estudam Relações Internacionais e aspiram reclamar seus direitos na ONU: como a estudante Pedrina Rosário, que já esteve nas Nações Unidas e pretende avançar com a luta quilombola também fora do Brasil.

Contudo, as recentes tormentas políticas do país colocaram os Malês numa situação de ainda maior indeterminação. $\mathrm{O}$ atual deslocamento da política externa brasileira, antes voltada ao Sul Global, direcionou-se mais para o Norte, promovendo o desengajamento diplomático do Brasil com os países africanos, chegando a ameaçar o fechamento de embaixadas naquele continente quando José Serra foi Ministro das Relações Exteriores (2016-2017). Também o chamado "teto de gastos” nos investimentos sociais produziu impactos locais já em 2018, quando por pouco o campus não foi anexado à Universidade Federal da Bahia (UFBA). $\mathrm{O}$ crescimento do nacionalismo branco e de extrema direita, junto com o avanço do discurso sexista, racista e xenófobo na esfera pública, desestabilizaram ainda mais a universidade, de modo que, em 2019, um tuíte do recém-empossado presidente da república contestou o edital de cotas para estudantes "trans e intersex" da Unilab. O edital foi inviabilizado pelo Ministério da Educação, um ato lido localmente como um ataque direto, promovendo medo e insegurança, inclusive em relação à permanência do edital para estudantes quilombolas e indígenas. Este, por fim, acabou sofrendo um corte considerável de vagas no ano de 2020, o que determinou, nos Malês, a ausência de estudantes quilombolas já no primeiro semestre deste ano.

A bolsa-auxílio dos estudantes internacionais é outro campo de disputas na universidade. E ela é importante não apenas por garantir a presença dos africanos no campus, mas porque torna possível a conexão entre as duas margens do Atlântico, um aspecto fundamental do projeto da Unilab. $\mathrm{O}$ advento do Coronavírus a partir de março de 2020 apenas abriu espaço para mais uma crise sobreposta, entre as inúmeras e sucessivas vulnerabilidades acumuladas naquele espaço. As respostas de enfrentamento à pandemia criadas pela comunidade universitária têm revelado formas inovadoras de solidariedade e ajuda mútua. O futuro do campus permanece incerto, mas em todo caso, temos aprendido que a história do povo negro é uma longa história de luta, ali relembrada e proclamada por estudantes, professores e funcionários sob a palavra de ordem "Malês resiste!". 


\section{Referências}

ALMEIDA, Miguel Vale. O Atlântico Pardo. Antropologia, pós-colonialismo e o caso "lusófono". In: BASTOS, Cristiana; ALMEIDA, Miguel Vale de; FELDMAN-BIANCO, Bela. Trânsitos coloniais: diálogos críticos luso-brasileiros. Campinas: Editora Unicamp, 2007.

AMORIM, Liane Alves. Memórias e Trajetórias de trabalhadores da cana de açúcar na Bahia (1909-1969). Dissertação (Mestrado em História) - Universidade Federal da Bahia, Salvador, 2008.

ARAÚJO, Marta; MAESO, Sílvia R. O poder do racismo na academia: produção de conhecimento e disputas políticas. In: SANTOS, Boaventura de Sousa; MARTINS, Bruno Sena, o pluriverso dos direitos humanos: a diversidade das lutas pela dignidade. Belo Horizonte: Autêntica, 2019.

ASSOCIAÇÃO QUILOMBOLA DOM JOÃO. Quilombo Dom João em Defesa do Meio Ambiente e contra o Derramamento e Contaminação de Petróleo - Carta Aberta da Comunidade Quilombola Dom João sobre o derramamento de petróleo ocorrido no dia 16 de maio de 2018. São Francisco do Conde, 2 jul. 2018.

BALDÉ, Mamadu. Mulheres africanas na UNILAB: registro de uma experiência em processo, Trabalho de Conclusão de Curso (Bacharelado Interdisciplinar em Humanidades) - UNILAB-Malês, São Francisco do Conde, 2017.

BARICKMAN, Bert Jude. Até a Véspera: o trabalho escravo e a produção de açúcar nos engenhos do Recôncavo Baiano (1850-1881). Afro-Ásia, n. 21-22, p. 177-238, 1998 1999.

BARROS, Zelinda; BARRETO, Paula Cristina da Silva; SANTOS, Marta Alencar dos; SOARES, Marília Carvalho. Educação e relações étnico-raciais. v. 1. Salvador: Programa A Cor da Bahia, 2013.

BEDAM, Amadú Victor. A imagem da África no Recôncavo baiano: conceitos sobre africanos em São Francisco do Conde-Bahia. Trabalho de Conclusão de Curso (Bacharelado Interdisciplinar em Humanidades) - Instituto de Humanidades e Letras, da UNILAB-Malês, São Francisco do Conde, 2017.

BENDO, Margarida Duete. Estranhamento e convivência dos estudantes africanos em São Francisco do Conde. Trabalho de Conclusão de Curso (Bacharelado Interdisciplinar em Humanidades) - Instituto de Humanidades e Letras, da UNILAB-Malês, São Francisco do Conde, 2017.

BOURDIEU, Pierre. Economia das trocas simbólicas. São Paulo: Perspectiva, 1992.

BRITO, Cristóvão. A PETROBRAS e a gestão do território no Recôncavo Baiano. Salvador: EDUFBA, 2008.

BUTI, Rafael Palermo. Imagens do Petroceno: habitabilidade e resistência quilombola nas infraestruturas do petróleo em manguezais do Recôncavo da Bahia. Amazônica. Revista de Antropologia, Belém, v. 12, n. 1, pp. 277-301, 2020.

CAM-NATE SUMBA, Julio Quintino, Estudantes africanos na UNILAB Campus dos Malês (São Francisco do Conde) entre os anos 2014-2018. Trabalho de Conclusão de Curso (Bacharelado Interdisciplinar em Humanidades) - Instituto de Humanidades e Letras, da UNILAB-Malês, São Francisco do Conde, 2019.

CARVALHO, Ana Paula Comin de; FERNANDES, Mariana Balen. O Negro no Recôncavo da Bahia: reflexões sobre construções identitárias, retóricas de etnicidade, raça e cultura. Ilha, Florianópolis, v. 21, n. 2, p. 7-34, 2019. 
CASIMIRO IÉ, Nivaldo. A imigração temporária dos estudantes guineenses na Bahia-Brasil: a procura de uma formação superior para o desenvolvimento nacional. Trabalho de Conclusão de Curso (Bacharelado Interdisciplinar em Humanidades) - Instituto de Humanidades e Letras, da UNILAB-Malês, São Francisco do Conde, 2016.

COSTA PINTO, Luiz de Aguiar. Recôncavo: o laboratório de uma experiência humana. In: BRANDÃO, Maria de Azevedo (Org.). Recôncavo da Bahia: sociedade e economia em transição. Salvador: Fundação Casa de Jorge Amado, 1998.

DJABI, Abdulai. Islamofobia e terrorismo: relatos e experiências de estudantes guineenses de intercâmbio acadêmico. Trabalho de Conclusão de Curso (Bacharelado Interdisciplinar em Humanidades) - Instituto de Humanidades e Letras, da UNILAB-Malês, São Francisco do Conde, 2017.

GADOTTI, Moacir. Pedagogia da terra: ecopedagogia e educação sustentável. CLACSO, Consejo Latinoamericano de Ciencias Sociales, Buenos Aires, 2001.

GEOGRAFAR, Relatório preliminar Comunidade Negra Rural quilombola Porto de Dom João São Francisco do Conde-BA. Salvador. POSGEO/UFBA, Salvador, 2015.

GILROY, Paul. O Atlântico Negro: modernidade e dupla consciência. São Paulo: Editora 34, 2001.

GÓES, Guilherme Sandoval; SILVA, Bruno Bahiense de Albuquerque e. Estados Unidos, China e a Geopolítica do Petróleo no Atlântico Sul: uma análise sob a ótica da teoria dos complexos regionais de segurança. Revista da Escola Superior de Guerra, v. 32, n. 64, p. 49-88, jan.-abr. 2017.

GONÇALVES, Ana Maria. Um defeito de cor. Rio de Janeiro: Record, 2006.

GRAMSCI, Antonio. Maquiavel, a política e o Estado moderno. Rio de Janeiro: Civilização Brasileira, 1991.

GUTIÉRREZ, Francisco; PRADO, Cruz. Ecopedagogia e cidadania planetária. São Paulo: Cortez, 1999.

HUTCHINSON, Harry William. Village and Plantation Life in Northeastern Brazil. Seattle: University of Seattle Press, 1957.

INGOLD, Tim. Estar vivo: ensaios sobre movimento, conhecimento e descrição. São Paulo: Vozes, 2015.

INGOLD, Tim. The perception of the environment: essays on livelihood, dwelling and skill. London: Routledge. 2002

LANGA, Ercílio N. B. Diáspora Africana no Ceará: desafios diante da alteridade e ressignificações de identidades étnico-raciais. In: VI CONGRESSO INTERNACIONAL DE ESTUDOS SOBRE A DIVERSIDADE SEXUAL E DE GÊNERO DA ABEH, 2012, Salvador, Bahia. Anais do Congresso Internacional de Estudos sobre a Diversidade Sexual e de Gênero da ABEH. Salvador, Bahia: NEHP/UFBA, Núcleo de Editoração de Homes Pages da Universidade Federal da Bahia, 2012, v. 1, p. 1-15.

MALOMALO, Bas'ilele. Desafios da gestão multicultural numa universidade internacional: caso da UNILAB. Tensões Mundiais, Fortaleza, v. 14, n. 26, p. 75-100, 2018.

MBEMBE, Achille. Decolonizing the university: new directions. Arts \& Humanities in Higher Education, v. 15, n. 1, p. 29-45, 2016.

MBEMBE, Achille. Sair da grande noite: ensaio sobre a África descolonizada. Petrópolis: Vozes, 2019.

MONIÉ, Frédéric. Petróleo, desenvolvimento e dinâmicas espaciais na África Subsaaria- 
na. In: MONIÉ, Frédéric; BINSZTOK, Jacob. Geografia e geopolítica do petróleo. Rio de Janeiro: FAPERJ, 2012.

MOREIRA, Paula Adelaide Mattos Santos; DINIZ, Edite Luiz; GUIMAR, Guiomar Inez; MACHADO, Silvio Marcio Montenegro. Comunidade Negra Rural Quilombola Porto Dom João: a Habitação no Contexto do Conflito por Terra. In: TERCEIRO COLÓQUIO HABITAT E CIDADANIA: HABITAÇÃO NO CAMPO, NAS ÁGUAS E NAS FLORESTAS, Brasília, 2015.

NASSER, Reginaldo M.; MORAES, Rodrigo F. (Orgs.). O Brasil e a segurança no seu entorno estratégico: América do Sul e Atlântico Sul. Brasília: IPEA, 2014.

NORA, Pierre. Entre história e memória: a problemática dos lugares. Revista Projeto História, São Paulo, v. 10, p. 7-28, 1993.

PENHA, Eli Alves. O dilema da geopolítica em Angola: entre o "Hearthland" africano e o Atlântico Sul. Tensões Mundiais, Fortaleza, v. 12, n. 22, p. 17-32, 2016.

PINTO, Naiane J. Experiência e memória: uma etnografia da experiência de Migração Forçada em Dom João em São Francisco Do Conde-BA. Trabalho de Conclusão de Curso (Bacharelado Interdisciplinar em Humanidades) - Instituto de Humanidades e Letras, da UNILAB-Malês, São Francisco do Conde, 2016.

PINTO, Naiane J. Território Falante: uma escrevivência das experiências e (r)existências do Quilombo Dom João. Trabalho de Conclusão de Curso (Licenciatura em Ciências Sociais) - Instituto de Humanidades e Letras, da UNILAB-Malês, São Francisco do Conde, 2019.

REIS, João. Rebelião escrava no Brasil: a história do levante dos Malês (1935). São Paulo: Brasiliense, 1986.

REIS, João. Recôncavo rebelde: revoltas escravas nos engenhos baianos. Afro-Ásia, n. 15, p. 100-126, 1992.

REIS, Luiza. África volta à Bahia. O Centro de Estudos Afro-orientais e o intercâmbio de estudantes africanos (1961-1965). In: TRAJANO FILHO, Wilson (Org.). Lugares, pessoas e grupos: as lógicas de pertencimento em perspectiva internacional. Brasília: Athalaia, 2010.

SÁ, Ana Lúcia. Guiné Equatorial e CPLP: desafios ao futuro da Lusofonia, Janus, 3.28, Integração regional e multilateralismo, 2015-2016.

SACHS, Jeffrey D.; WARNER, Andrew M. The curse of natural resources. European Economic Review, n. 45, p. 827-838, 2001.

SANGUIN, André-Louis. São Tomé e Príncipe, as ilhas do meio do mundo: avaliação crítica sobre sua geografia política, Confins, n. 20, 2014.

SANSONE, Lívio. Desigualdades duráveis, relações raciais e modernidades no Recôncavo: o caso de São Francisco do Conde. REVISTA USP, São Paulo, n. 68, p. 234-251, dez./fev. 2006.

SANSONE, Lívio. Um contraponto baiano de açúcar e petróleo: mercadorias globais, identidades globais? In: 26a . REUNIÃO BRASILEIRA DE ANTROPOLOGIA, 1-4 de junho de 2005. Porto Seguro, Bahia, 2005.

SANTANA, Jaciara. São Francisco do Conde e o enigma da riqueza e pobreza no Recôncavo Baiano. Dissertação (Mestrado em Planejamento Territorial e Desenvolvimento Social) - Universidade Católica de Salvador - UCSAL, Salvador, 2011.

SARAIVA, José Flavio Sombra. África Parceira do Brasil Atlântico: relações Internacionais do Brasil e da África no início do século XXI. Belo Horizonte: Fino Traço, 2012. 
SILVA, Kelly; MORAIS, Sara S. Tendências e tensões de sociabilidade de estudantes dos PALOP em duas universidades brasileiras. Pro-Posições, Campinas, v. 23, n. 1, jan. 2012. Disponível em: http://www.scielo.br/pdf/pp/v23n1/11.pdf. Acesso em: 30 nov. 2015.

SILVEIRA, Pedro Castelo Branco Silveira; BUTI, Rafael Palermo. A vida e a morte dos guaiamuns: antropologia nos limites dos manguezais. Anuário Antropológico, v. 45, n. 1, p. 117-148, 2020.

UNILAB, Ceará. UNILAB: caminhos e desafios acadêmicos da cooperação Sul-Sul. Org. de Camila Gomes Diógenes e José Reginaldo Aguiar. Redenção: UNILAB, 2013.

VERGER, Pierre. Fluxo e refluxo: tráfico de escravos entre o Golfo do Benin e a Bahia de Todos os Santos (séculos XVII-XIX). Salvador: Corrupio, 2002.

ZAGATTO, Bruna Pastro. Eu sou marisqueira, lavradora e quilombola: uma análise do processo de construção de identidade nas comunidades rurais do Guai, Maragojipe, Bahia. Dissertação (Mestrado em Antropologia) - Universidade Federal da Bahia, Salvador, 2011. 